\title{
Media Sosial dan Connective Action: Studi Kasus Penggunaan Twitter sebagai Ruang Solidaritas selama Pandemi COVID-19
}

\author{
Kristianto $^{1}$, Abdul Basith Ramadhan ${ }^{2}$, Fernandito Dikky Marsetyo ${ }^{3}$
}

\begin{abstract}
Abstrak
Tulisan ini membahas munculnya aksi solidaritas di media sosial Twitter. Dengan menggunakan kerangka teori connective action dan efektivitas gerakan di media sosial, tulisan ini bertujuan untuk menjelaskan bagaimana aksi solidaritas di Twitter muncul dan menjelaskan aktor yang terlibat di dalamnya. Selain itu, tulisan ini juga bertujuan untuk menjelaskan efektivitas dari aksi solidaritas. Penelitian dilakukan dengan analisis media sosial dan analisis konten. Penelitian menunjukkan bahwa aksi solidaritas yang muncul di Twitter merupakan respons atas situasi krisis akibat pandemi COVID-19. Meskipun merespons isu dalam rentang waktu yang sama dan menggunakan narasi yang serupa, aksi solidaritas yang dimunculkan oleh individu, organisasi, dan komunitas dilakukan secara personal dan tidak saling terikat secara langsung. Namun demikian, tidak semua aksi solidaritas mendapatkan impresi/engagement yang tinggi. Aktor yang menjadi opinion leader, yang dipengaruhi oleh faktor indegree, retweet dan mention, memiliki pengaruh besar dalam melakukan aksi solidaritas.
\end{abstract}

Kata kunci: solidaritas; krisis; opinion leader; twitter; connective action

\begin{abstract}
This article discusses the emergence of solidarity actions on Twitter social media. Using the framework of connective action and the effectiveness of social media movements, this paper aims to explain how solidarity actions on Twitter emerge and explain the actors involved in it. Besides, this paper also aims to explain the effectiveness of solidarity actions. The research was conducted with social media analysis and content analysis. Research shows that the solidarity action that appears on Twitter is a response to the crisis caused by the COVID-19 pandemic. Although responding to issues in the same time frame and using similar narratives, solidarity actions raised by individuals, organizations, and communities are carried out personally and are not directly tied to each other. However, not all solidarity actions received high impressions/engagement. Actors who are opinion leaders, who are influenced by indegree, retweet, and mention factors, have a big influence in carrying out solidarity actions.
\end{abstract}

Keywords: solidarity; crisis; opinion leader; twitter; connective action

\section{Pendahuluan}

Coronavirus Disease 2019 (COVID-19) menjadi isu global yang berkembang sejak akhir tahun 2019. WHO mendeklarasikan COVID-19 sebagai pandemi global setelah virus tersebut menyebar ke lebih dari 100 negara dalam kurun waktu tiga bulan (World Health Organization, 2020c). Berdasarkan data WHO pada 12 September 2020, jumlah kasus konfirmasi positif di seluruh dunia mencapai 28.329 .790 orang dengan jumlah kematian mencapai 911.899 jiwa (World Health Organization, 2020d). Indonesia secara resmi mengumumkan kasus terkonfirmasi positif pertama pada 2 Maret 2020 (Kompas, 2020a). Sejak kasus pertama muncul, jumlah kasus terkonfirmasi positif di Indonesia terus meningkat. Hingga 12 September 2020, jumlah kasus terkonfirmasi positif di Indonesia mencapai 210.940 orang dengan jumlah kematian mencapai 8.544 jiwa (World Health Organization, 2020c).

Meningkatnya jumlah kasus terkonfirmasi positif COVID-19 di Indonesia dikhawatirkan dapat melumpuhkan sistem pelayanan kesehatan masyarakat. Kekhawatiran tersebut bukan tanpa dasar. Secara global, pandemi COVID-19

\footnotetext{
${ }^{1}$ Departemen Manajemen dan Kebijakan Publik, Universitas Gadjah Mada (email korespondensi: kristianto.mkp@mail.ugm.ac.id)

${ }^{2}$ Departemen Manajemen dan Kebijakan Publik, Universitas Gadjah Mada (email: abdul.basith.ramadhan@mail.ugm.ac.id)

${ }^{3}$ Departemen Pembangunan Sosial dan Kesejahteraan, Universitas Gadjah Mada (email: fernandito.d@mail.ugm.ac.id)
} 
Kristianto, Abdul Basith Ramadhan, Fernandito Dikky Marsetyo - Media Sosial dan Connective Action: Studi Kasus Penggunaan Twitter sebagai Ruang Solidaritas selama Pandemi COVID-19

telah memorak-porandakan sistem pelayanan kesehatan di berbagai negara. Kebutuhan akan fasilitas medis yang naik tajam dalam hitungan hari, membuat banyak negara kewalahan dan memaksa keras sistem kesehatannya (CNBC Indonesia, 2020). Kondisi tersebut memunculkan adanya gangguan rantai pasokan Alat Pelindung Diri (APD) yang membuat persediaannya menjadi terbatas (World Health Organization, 2020b). Indonesia juga mengalami hal serupa. Pertumbuhan kasus harian terkonfirmasi terus menunjukkan peningkatan (Satuan Tugas Penanganan COVID-19 Indonesia, 2020). Hal ini membuat kapasitas fasilitas kesehatan, baik dari sisi ketersediaan rumah sakit rujukan COVID-19, jumlah tempat tidur, jumlah ruangan ICU, hingga ventilator menjadi semakin terbatas (Tirto, 2020). Tidak hanya itu, tenaga medis juga mengalami kekurangan APD sejak akhir Maret 2020 (Kompas, 2020b; Viva, 2020).

Guna mengurangi penyebaran COVID-19, WHO menghimbau negara-negara di dunia untuk menerapkan kebijakan physical distancing (World Health Organization, 2020a). Di Indonesia, hal ini diwujudkan melalui penetapan status keadaan darurat bencana COVID-19 dan Pembatasan Sosial Berskala Besar (PSBB) di berbagai wilayah (Kemenko PMK, 2020). Dampaknya, aktivitas kerja dan produksi ekonomi menjadi terhambat bahkan berhenti. Secara sederhana, aktivitas ekonomi terjadi dengan adanya transaksi pertukaran barang dan jasa, baik secara fisik maupun daring (Basri, 2020). Namun, kebijakan yang diterapkan pemerintah untuk mengurangi penyebaran COVID-19 dengan membatasi pergerakan orang, juga mempersempit kesempatan pelaku ekonomi dan konsumen untuk melakukan transaksi secara fisik. Berdasarkan data Google COVID-19 Community Mobility Report, secara rata-rata nasional pergerakan manusia ke tempat ritel dan rekreasi menunjukkan penurunan (Google, 2020). Imbasnya, sebanyak $98 \%$ usaha pada level mikro atau sekitar 63 juta terkena dampak (Wiharso, 2020). Survei oleh Smesco Indonesia juga menunjukkan pelaku Usaha Mikro, Kecil, dan Menengah (UMKM) dari berbagai sektor juga mengalami penurunan omset secara drastis (Kontan, 2020).

Paparan tersebut menggambarkan bahwa adanya pandemi COVID-19 telah menghadapkan masyarakat pada ancaman krisis yang nyata, yakni krisis kesehatan dan ekonomi. Merespons kondisi demikian, muncul berbagai aksi solidaritas untuk merespons krisis yang terjadi. Aksi solidaritas muncul pada ruang virtual bernama media sosial (Fisse \& Hass, 2020). Salah satu media sosial tersebut adalah Twitter. Twitter menciptakan sebuah ruang di mana setiap individu dapat terlibat dalam percakapan berjejaring yang tidak terpengaruh oleh batasan sosial, ruang, dan waktu (Ausserhofer \& Mairader, 2013). Kemunculan jejaring sosial seperti Twitter menawarkan sebuah wujud baru dari ruang yang berbentuk virtual untuk melakukan diskusi kolektif, proses negosiasi, dan solidaritas sosial (Fisse \& Hass, 2020).

Indonesia tercatat menjadi pengguna Twitter terbesar kelima di dunia (Herman \& Mononimbar, 2017). Dalam konteks Indonesia, gerakan melalui Twitter bukanlah hal baru. Sebagai contoh, Twitter digunakan sebagai medium untuk membentuk opini publik (Suwana, 2020), mobilisasi massa aksi politik (Ahyar \& Alfitri, 2019), dan menggalang dana bantuan (Fammy et al., 2020). Dalam konteks pandemi COVID-19, berbagai aksi solidaritas beberapa kali tercatat di inisiasi melalui Twitter (Anggraeni, 2020; Dinisari, 2020). Aksi solidaritas ini saling bantu-membantu untuk memenuhi kebutuhan dasar masyarakat terdampak pandemi COVID-19 (Raditya, 2020; Syambudi, 2020) dan memenuhi alat-alat yang dibutuhkan oleh tenaga kesehatan, seperti Alat Pelindung Diri (APD), sebagai garda terdepan menangani virus COVID-19 (Anggraeni, 2020; Kumparan, 2020).

Fenomena aksi solidaritas melalui Twitter selama pandemi COVID-19 berlangsung perlu dikaji lebih lanjut. Tulisan ini akan menjelaskan bagaimana aksi solidaritas di Twitter muncul dan menjelaskan siapa saja aktor yang melakukan aksi solidaritas. Selanjutnya, tulisan ini juga akan membahas mengenai bagaimana efektivitas aksi solidaritas tersebut.

\section{Kerangka Teori}

Connective Action

Studi ini memiliki dua fokus utama. Fokus pertama adalah menganalisis bagaimana aksi solidaritas di Twitter muncul dan menjelaskan siapa saja aktor yang melakukan aksi solidaritas. Fokus kedua adalah menganalisis bagaimana efektivitas gerakan solidaritas yang dilakukan oleh beragam aktor di Twitter. Untuk menjawab fokus pertama pada studi ini, 
penulis menggunakan konsep connective action yang dipopulerkan oleh Bennett \& Segerberg (2013) dalam bukunya yang berjudul "The Logic of Connective Action: Digital Media and the Personalization of Contentious Politics".

Connective action adalah sebuah konsep yang menjelaskan bahwa gerakan sosial di era sekarang mungkin saja tidak memiliki pemimpin, tidak memiliki struktur organisasi yang jelas, dan seorang anggota dapat dengan mudah bergabung atau meninggalkan sebuah aksi (Bennett \& Segerberg, 2012). Hal ini terjadi karena kehadiran media sosial berperan utama dalam menyediakan ruang publik baru untuk melakukan aksi dengan pola baru yang tidak pernah terbayangkan sebelumnya (Iosifidis \& Wheeler, 2016). Jika collective action memberikan syarat bahwa sebuah aksi harus memiliki ikatan keorganisasian, memiliki struktur organisasi, serta memiliki seorang pemimpin dalam menjalankan sebuah aksi, connective action justru lebih mengandalkan tindakan individu daripada tindakan kolektif (Bennett \& Segerberg, 2013). Inti dari connective action yang membedakannya dari aksi tradisional adalah pada penggunaan teknologi sebagai agen penyelenggara (organising agents). Aksi tradisional menggunakan teknologi sebagai alat atau instrumen (technology-as-instrument). Sedangkan dalam connective action, teknologi digunakan sebagai konteks gerakan (technologyas-context) (Bimber, 2017).

Connective action memiliki tiga karakteristik utama. Pertama, individu tidak harus memiliki komitmen terhadap kelompok tertentu. Individu dapat berpartisipasi tanpa perlu menjadi anggota dalam sebuah gerakan. Faktor kesamaan pandangan terhadap suatu isu menjadi faktor utama yang menjadi penyebab mengapa individu tergabung dalam connective action. Kedua, partisipasi dalam ranah digital lebih menekankan pada ekspresi personal, alih-alih ekspresi dari sebuah kelompok. Tagar (hashtag) dan kata kunci (keyword) menjadi bingkai untuk menyuarakan suatu isu dan bisa saja berbeda-beda dari setiap individu. Ketiga, jejaring komunikasi menjadi cara utama untuk mengorganisir suatu gerakan di media sosial, alih-alih menggunakan hierarki dan keanggotaan organisasi. Jejaring komunikasi melalui ruang virtual ini yang akan mengoordinir sebuah aksi, sehingga memungkinkan setiap individu tidak perlu saling mengenal dan tatap muka untuk menjalankan sebuah aksi.
Dalam studinya, Bennett \& Segerberg (2012) mengidentifikasi tiga tipologi jejaring aksi (action network). Satu dari tiga tipologi diantaranya merupakan jaringan organisasi yang diperantarai (organizationally brokered networks) dan dicirikan dengan logika collective action. Sementara dua tipologi lainnya mewakili variasi pada jaringan yang dicirikan dengan logika connective action. Tipologi pertama adalah self-organizing network. Pada tipologi ini, sebuah gerakan menggunakan connective action tanpa adanya struktur hierarki organisasi untuk mengoordinasikan tindakan. Komunikasi didasarkan pada kerangka tindakan pribadi yang menekankan pada inklusivitas dan berbagi (sharing) opini, pengalaman, dan keresahan pribadi di media sosial. Dalam jaringan ini, individu dipahami sebagai unit transmisi yang saling terhubung dengan individu lainnya.

Tipologi kedua adalah organizationally brokered network. Tipologi ini mewakili collective action dengan adanya struktur hierarki, koordinasi terpusat dari sebuah organisasi, dan kerangka aksi kolektif untuk memfasilitasi mobilisasi dan partisipasi. Organisasi menggunakan teknologi untuk mengelola partisipasi gerakan (merekrut anggota) dan mengoordinasikan tujuan (melakukan publikasi). Anggota organisasi tetap menjadi aktor inti dalam mobilisasi. Mereka merumuskan bingkai collective action untuk menarik orang agar turut berpartisipasi dalam gerakan.

Tipologi ketiga adalah organizationallyenabled action. Tipologi ini merupakan gabungan antara logika collective action dan connective action. Di sini organisasi formal tidak memiliki peran utama dalam gerakan, sehingga tipe ini dicirikan oleh tindakan organisasi yang lebih longgar. Organisasi cenderung berperan sebagai 'aktor di belakang panggung' dalam mobilisasi sumber daya, alih-alih menggunakan pendekatan secara hierarkis komando. Mereka memberdayakan anggota organisasi untuk mempertimbangkan tujuan dan mengoordinasikan tindakan kolektif. Organisasi pada jenis ini utamanya memanfaatkan media sosial untuk membantu individu mengembangkan rasa komunitas mereka. Pada tipologi ini, media sosial digunakan untuk memperluas jaringan dengan gerakan sosial ataupun organisasi lainnya. 
Kristianto, Abdul Basith Ramadhan, Fernandito Dikky Marsetyo - Media Sosial dan Connective Action: Studi Kasus Penggunaan Twitter sebagai Ruang Solidaritas selama Pandemi COVID-19

\section{Connective Action dan Efektivitas Gerakan di Media Sosial}

Kendati Bennet dan Segerberg melalui studinya telah memberikan kontribusi teoritik dalam menjelaskan bagaimana pola aktivisme baru di media sosial, akan tetapi studi tersebut belum menjawab pertanyaan kritisyang diajukan oleh Lim (2013) tentang, "Apa saja yang harus dilakukan untuk memastikan keberhasilan dan keterlibatan sipil dalam aktivisme digital?". Sedangkan di sisi lain, Bennett \& Segerberg (2012) menjelaskan bahwa pada dasarnya partisipasi di media sosial berasal dari ekspresi individu. Gerakan di media sosial perlu dilihat sejauh mana efektivitasnya dalam menggalang dukungan.

Oleh karena itu untuk menjawab fokus kedua pada studi ini, penulis menawarkan sebuah kerangka berpikir untuk mengisi celah tersebut. Penulis menggunakan studi yang dilakukan oleh Lim (2013) yang berjudul "Many Clicks but Little Sticks: Social Media Activism in Indonesia" dan konsep Social Media Opinion Leader (Luarn et al., 2014; Park, 2013; Zhang et al., 2016; Xu et al., 2014). Lim (2013) dalam studinya berpendapat bahwa gerakan di media sosial dapat berhasil memobilisasi dukungan masa ketika berhasil mencapai tiga hal, diantaranya: (1) adanya narasi yang disederhanakan (simplified narratives), (2) adanya representasi simbolik (symbolic representation), dan (3) aktivisme berisiko rendah (low-riskactivism). Media sosial merupakan tempat di mana informasi beredar begitu cepat, banyaknya informasi yang beredar, dan percakapannya cukup singkat. Sehingga, hal ini memunculkan adanya kecenderungan individu untuk mengikuti isu berdasarkan selera mereka.

Dengan kata lain, narasi sederhana dapat menjadi sesuatu yang viral. Sebuah isu dibingkai sedemikian rupa sehingga menjadi judul pendek, menarik, dan sensasional agar lebih banyak mendapat perhatian publik. Berangkat dari narasi sederhana dan sebuah isu yang dibingkai dengan sedemikian rupa, maka suatu gerakan dapat memiliki simbol yang dapat merepresentasikan isu yang ada di dalamnya. Aktivisme berisiko rendah cenderung mendorong lebih banyak partisipasi. Akan tetapi, risiko tidak selalu terkait dengan tindakan. Tindakan berisiko rendah, seperti melakukan berbagi (share) informasi, dapat menjadi berisiko tinggi jika gerakan tersebut mewakili atau menyuarakan pendapat dari non-arus utama (non-mainstream opinion) (Lim, 2013). Walaupun demikian, ukuran keberhasilan mobilisasi masa di media sosial yang dijelaskan oleh Lim (2013) luput dalam memahami seperti apa aktor yang memiliki pengaruh besar dalam melakukan mobilisasi gerakan di media sosial. Oleh karena itu, penulis menggunakan konsep mengenai Social Media Opinion Leader.

Menurut Jungherr (2015) sebuah isu yang muncul di media sosial (terutama di Twitter) tidak muncul dengan sendirinya, melainkan terdapat aktor ataupun kelompok yang memunculkan sebagai percakapan di media sosial untuk menarik perhatian pengguna lainnya. Di media sosial perhatian merupakan aset paling berharga. Pengguna yang berhasil tidak hanya mendapatkan perhatian saja, namun juga memiliki pengaruh besar terhadap pengguna lain untuk melakukan suatu tindakan ataupun menyebarkan lebih luas atas sebuah isu (Xu et al., 2014). Seseorang yang memiliki pengaruh besar di media sosial disebut sebagai opinion leader (Park, 2013; Zhang et al., 2016).

Pada dasarnya, opinion leader yang ada di media sosial (terutama di Twitter) memiliki sedikit perbedaan dengan opinion leader tradisional. Misalnya saja, seorang opinion leader di Twitter dipengaruhi oleh faktor latar belakang keahlian dan opini yang disuarakan di media sosial, dibandingkan dengan status sosialnya. Dengan kata lain, tingkat pendidikan dan status sosial seorang pengguna di media sosial tidak menjadi masalah. Namun, opinion leader yang ada di media sosial lebih dipengaruhi oleh status informal yang menyebabkan mereka memiliki konektivitas atau keterhubungan lebih kuat dengan pengguna lainnya. Jaringan keterhubungan (konektivitas) seorang individu yang lebih luas dengan individu lainnya merupakan ciri utama yang membedakan opinion leader di media sosial dengan opinion leader tradisional (Park, 2013). Menurut Cha (dalam Zhang et al. 2016), seorang opinion leader yang ada di Twitter dapat diukur dari tiga ukuran: indegree (jumlah pengikut suatu akun di Twitter), retweet (jumlah twit yang dibuat pengguna yang telah di-retweet oleh akun lainnya), dan mention (berapa kali suatu akun disebutkan di twit pengguna lain). Luarn et al. (2014) menemukan bahwa orang yang memiliki lebih banyak konektivitas di media sosial, memiliki pengaruh yang lebih besar dalam penyebaran informasi di media sosial. 


\section{Metode Penelitian}

Penelitian ini menggunakan metode analisis media sosial (social media analytics) dan analisis konten (content analytics). Analisis media sosial merupakan alat dan kerangka kerja untuk mengumpulkan, menganalisis, meringkas, dan memvisualisasikan data dari media sosial yang tidak terstruktur (Stieglitz \& Dang-Xuan, 2013) dengan tujuan utamanya memfasilitasi percakapan dan interaksi antar komunitas daring serta menganalisis pola dalam dialog di media sosial (Zeng et al., 2010). Analisis media sosial digunakan untuk mengidentifikasi impresi yang didapatkan oleh sebuah twit dan akun yang digunakan untuk melakukan kampanye solidaritas selama pandemi COVID-19. Hal tersebut dapat dilihat melalui berapa banyak jumlah like, retweet, dan reply yang didapatkan. Untuk memperkuat analisis media sosial, penelitian ini juga menggunakan analisis konten untuk memperdalam analisis berdasarkan pesan yang muncul. Analisis konten digunakan pada penelitian ini untuk memeriksa informasi dan konten dalam materi tertulis serta melakukan pemaknaan secara objektif dari sebuah twit, mengaktualisasikan terhadap latar belakang aktor, dan memahami kejadian ketika twit tersebut muncul.

Data dalam penelitian ini diperoleh dari pihak ketiga yakni PT. Kedata Indonesia Digital. Peneliti mengajukan permohonan izin akses data scraping kepada PT. Kedata Indonesia Digital untuk menggunakan perangkat lunak yang dimiliki oleh institusi tersebut. Langkah pertama yang dilakukan peneliti adalah melakukan eksplorasi terhadap kata kunci dan tagar yang berpotensi untuk menjadi sampel. Berangkat dari proses eksplorasi yang dilakukan, kemudian ditemukan 3 (tiga) kata kunci yakni "donasi covid", "transfer donasi", dan "donasi kemanusiaan" serta 2 (dua) tagar atau hashtag yakni "\#SalingJaga" dan "\#PeduliCovid". Kata kunci dan tagar tersebut dipilih dikarenakan dalam proses eksplorasi ditemukan twit yang langsung mengarah pada hal yang berhubungan dengan solidaritas sosial dan pandemi COVID-19 seperti ajakan untuk berdonasi serta terdapat lebih dari 10 twit yang mendapatkan impresi tinggi. Adapun periode waktu twit yang diambil adalah tanggal 14 Maret 2020 (awal pemberlakuan pembatasan sosial) hingga 31 Juli 2020 (masa kenormalan baru/ adaptasi kebiasaan baru).
Data scraping dilakukan terhadap sampel sebanyak 10.000 twit pada masing-masing kata kunci dan hashtag. Hasil data yang didapatkan dari data scraping tersebut tersaji dalam bentuk dokumen Microsoft Excel dan Dokumen Endgraf yang kemudian dokumen-dokumen tersebut digunakan sebagai bahan analisis dalam penelitian ini. Dokumen Endgraf menyediakan 2 (dua) komponen utama yang dijadikan sebagai data analisis yakni engagement dan buzzword. Data Engagement digunakan untuk melakukan analisis media sosial dikarenakan terdapat data nama akun beserta jumlah pengikut, jumlah suka, balasan, dan akun yang disebut dalam sebuah twit. Data Endgraf digunakan untuk melakukan analisis konten dikarenakan memuat kata yang paling sering digunakan pada masing-masing tagar dan kata kunci. Kata yang paling sering digunakan tersebut memberikan gambaran bagaimana bentukjalinan solidaritas diarahkan. Analisis media sosial dan analisis konten terhadap kata kunci dan tagar tersebut berguna untuk menjelaskan connective action yang terjadi selama pandemi COVID-19 berupa bagaimana gerakan solidaritas di Twitter muncul, siapa aktor-aktor yang terlibat, dan bagaimana efektivitas dari gerakan tersebut.

\section{Hasil \\ Respons Atas Pandemi COVID-19}

Pandemi COVID-19 di Indonesia telah menggerakkan pengguna media sosial Twitter untuk memberikan respons atas situasi krisis yang terjadi. Respons tersebut dapat dilihat melalui analisis konten pada data buzzword atau kata yang paling sering digunakan pada setiap kata kunci dan tagar yang dianalisis. Adanya buzzword tersebut memberikan gambaran bahwa respons diarahkan pada dua sektor yakni ekonomi dan kesehatan.

Analisis konten pada twityang menggunakan kata kunci "donasi kemanusiaan" memunculkan beberapa kata yang dominan dan paling digunakan yaitu kata "ayo" "bantu”, "Indonesia", "covid", "peduli", dan "bantuan". Pada kata kunci ini dapat dilihat adanya penggunaan kata persuasif yang ditunjukkan dengan penggunaan kata-kata tersebut.

Pada kata kunci "donasi covid", dapat dilihat bahwa ajakan solidaritas polanya dapat terlihat jelas dari kata yang sering digunakan oleh pengguna Twitter. Kata tersebut setidaknya memiliki tiga unsur yakni kata ajakan, krisis yang sedang terjadi, dan tujuan penyaluran donasi. 
Kristianto, Abdul Basith Ramadhan, Fernandito Dikky Marsetyo - Media Sosial dan Connective Action: Studi Kasus Penggunaan Twitter sebagai Ruang Solidaritas selama Pandemi COVID-19

\section{Gambar 1}

Kata Dominan dan Paling Banyak Digunakan dalam Kata Kunci “Donasi Kemanusiaan”

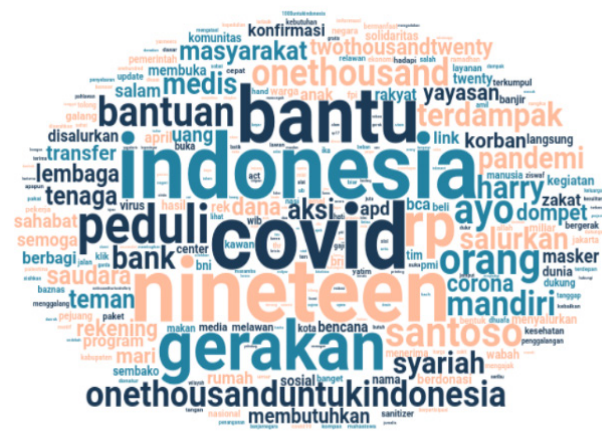

Sumber: Olahan Peneliti, 2020

Gambar 2

Kata Dominan dan Paling Banyak Digunakan

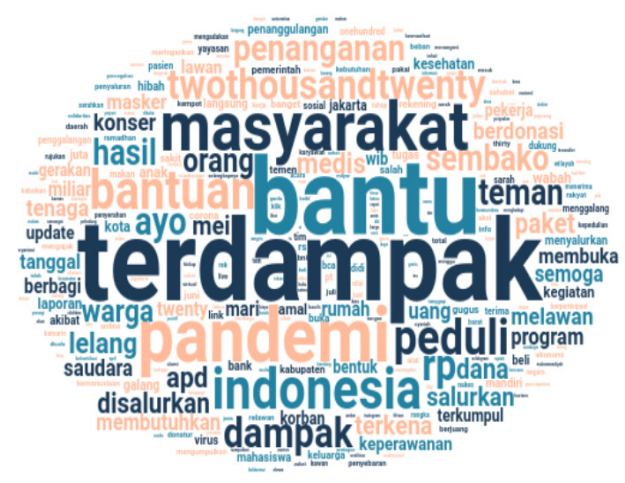

Sumber: Olahan Peneliti, 2020

Kata kunci "transfer donasi" sedikit menunjukkan pola yang berbeda jika dibandingkan dengan dua kata kunci sebelumnya. Kata kunci ini lebih menunjukkan bagaimana sumber daya hasil donasi dikumpulkan. Hal tersebut ditunjukkan dengan kata yang paling sering digunakan seperti "rekening", "konfirmasi", dan beberapa kata yang merupakan nama-nama layanan perbankan.

Selanjutnya, analisis konten pada tagar \#SalingJaga menunjukkan bahwa tagar ini digunakan dengan pola yang hampir sama dengan kata kunci "donasi covid" dan "donasi kemanusiaan" yakni adanya ajakan (yang bersifat persuasif) untuk saling membantu satu sama lain di tengah situasi krisis yang terjadi. Hal tersebut ditunjukkan dengan kata yang paling sering digunakan seperti kata "ayo" dan "bantu".

Tagar terakhir yang digunakan dalam studi ini adalah \#Peduli Covid. Tagar ini menunjukkan data yang sedikit berbeda dengan kata kunci dan

\section{Gambar 3}

Kata Dominan dan Paling Banyak Digunakan dalam Kata Kunci "transfer donasi”

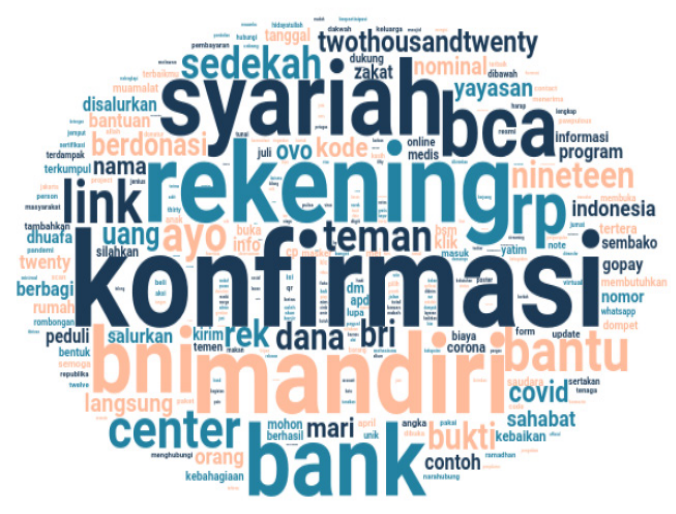

Sumber: Olahan Peneliti, 2020

Gambar 4

Kata Dominan dan Paling Banyak Digunakan dalam Kata Kunci “\#SalingJaga”

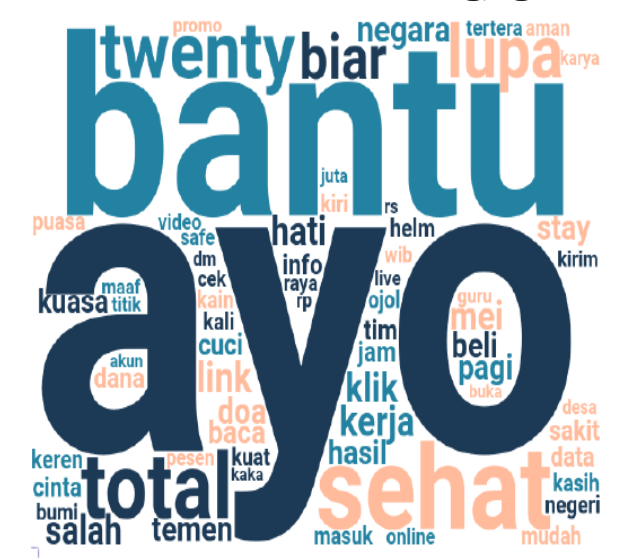

Sumber: Olahan Peneliti, 2020

Gambar 5

Kata Dominan dan Paling Banyak Digunakan

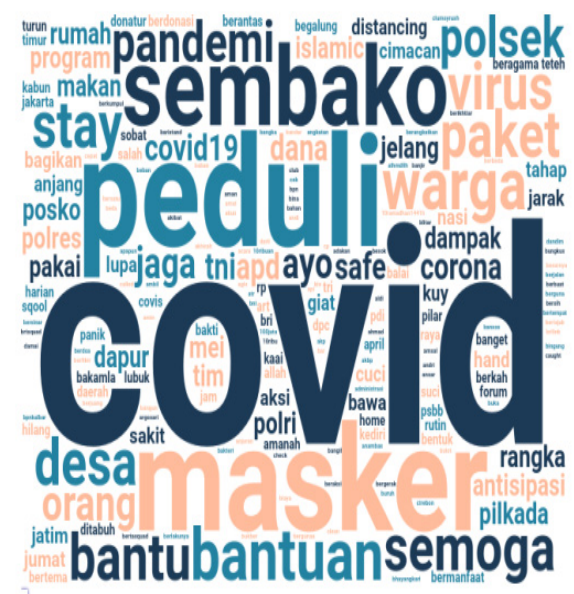

Sumber: Olahan Peneliti, 2020 
tagar lain berupa respons atas situasi krisis yang lebih spesifik. Kata yang paling sering digunakan seperti "masker" dan "sembako" menunjukkan bahwa para pengguna sosial media Twitter mengarahkan respons mereka pada dua sektor utama yakni kesehatan dan ekonomi.

\section{Klasifikasi Aktor}

Data endgraf dari tiga kata kunci dan dua tagar menunjukkan adanya variasi aktor yang beragam. Penulis mengelompokkan aktor-aktor tersebut menjadi 3 (tiga) kategori aktor, yakni individu/personal, organisasi, dan komunitas. Pada kata kunci "transfer donasi" misalnya, terdapat salah satu akun yang mendapatkan engagement cukup besar yakni @baznasindonesia. Akun tersebut adalah milik Badan Amil dan Zakat Nasional yang merupakan organisasi milik pemerintah. Selain itu juga terdapat organisasi sosial non pemerintah seperti@rumahzakat, @SRBergerakdan @baitulyatim yang merupakan tiga akun paling aktif yang menggunakan kata kunci tersebut. Ada pula akun individu/personal yakni @ghinaagaliya yang mengajak untuk turut berpartisipasi dalam penggalangan dana.

Pada kata kunci "donasi kemanusiaan" terlihat beberapa akun twitter milik organisasi yang bergerak dalam bidang amal dan sosial kemanusiaan. Lembaga tersebut diantaranya: Rumah Zakat, Dompet Dhuafa, Human Initiative, Dhuha Umat, dan Ambulans Syariah. Lembagalembaga tersebut menjadi pengisi sepuluh besar akun yang paling banyak menggunakan kata kunci tersebut. Akun platform donasi digital, @kitabisacom juga turut mengampanyekan pembukaan donasi yang tersedia di platformnya. Salah satu cuitan akun tersebut mendapatkan retweet lebih dari 1.000 kali.

Analisis pada kata kunci "donasi covid" menunjukkan adanya variasi aktor. Pada daftar pengguna yang paling aktif mengirim twit, terdapat beberapa media massa yang bertengger pada jajaran 10 (sepuluh) besar seperti@republikaonline, @mediaindonesia, @liputan6dotcom, hingga media radio yakni @RadioElshinta. Secara umum media-media tersebut mengambil peran sebagai penyebar berita tentang kegiatan solidaritas, seperti penggalangan dana yang dilakukan oleh pihakpihak lain. Hal tersebut dapat dilihat dari salah satu twit dari @detikcom yang memberitakan penggalangan dana yang dilakukan oleh penyanyi
Didi Kempot. Twit tersebut mendapatkan total engagement 7290 dan menjadi twit dengan engagement tertinggi.

Selain digunakan oleh media massa, kata kunci "donasi covid" juga dimanfaatkan oleh para selebriti dalam mengampanyekan aksi solidaritas yang mereka lakukan. Salah satunya adalah grup musik JKT 48 yang dapat dilihat dalam twit yang diunggah pada tanggal $22 \mathrm{Mei}$ 2020. Twit tersebut berhasil mendapatkan total 2033 engagement. Kampanye untuk menggalang solidaritas membantu masyarakat terdampak pandemi COVID-19 tidak hanya terbatas pada sektor-sektor yang diakui secara formal oleh negara. Perhatian terhadap kelompok marginal seperti kelompok waria juga mewarnai lini masa Twitter. Salah satunya dapat dilihat dari twit pengguna Twitter dengan nama akun @ nurdiyansah yang mengajak para pengguna twitter untuk membantu meringankan beban para waria. Twit tersebut mendapatkan total engagement sebanyak 2407.

Selanjutnya, pada tagar \#SalingJaga, terdapat beberapa akun Twitter yang tercatat paling sering mengirim twit dengan mencantumkan hashtag tersebut, diantaranya: GUSDURians, gusdurianpeduli, SLBN2Jogja, GusdurianMadiun, DDSumut, GusdurianSMG, dutadamaisulsel, dan BaskoroKat. Tagar \#SalingJaga menjadi salah satu alat penghubung dan juga alat untuk mengampanyekan solidaritas di Twitter selama pandemi terjadi. Tercatat terdapat lima akun dengan twit yang mencantumkan \#SalingJaga memiliki engagement tertinggi. Kelima akun tersebut merupakan tokoh publik yang terkenal di masyarakat. Sebuah twit dari akun @na_dirs milik akademisi ternama, Nadirsyah Hosen, mengajak warganet untuk membantu para pengemudi ojek daring dengan memesan makanan via aplikasi ojek daring, namun makanan tersebut diberikan kepada pengemudinya. Twit tersebut mendapat 3.870 engagement.Twit dari @na_dirs yang lain yang memakai hashtag tersebut juga tercatat mendapatkan 2.849 engagement. Sementara itu twit dari akun personal lain seperti @ sudjiwotedjo mendapatkan 1.692 engagement dan @najwashihab mendapatkan engagement sebanyak 1.385 .

Terakhir, terdapat beberapa akun Twitter yang tercatat paling sering mengirim twit dengan mencantumkan tagar \#PeduliCovid, antara lain: Lihwana2, RAhmadA89471496, 
Kristianto, Abdul Basith Ramadhan, Fernandito Dikky Marsetyo - Media Sosial dan Connective Action: Studi Kasus Penggunaan Twitter sebagai Ruang Solidaritas selama Pandemi COVID-19

PolsekWrkondang, polrestanahkaro, IslamicYouthca1, pedulicovid19, papanyasinok, LukasCahya, dan jpnncom. Walaupun tagar \#PeduliCovid sering digunakan, namun seluruh twit yang menggunakan tagar tersebut tercatat tidak banyak mendapatkan engagement. Pertama, sebuah twit dari lembaga pengelola zakat Dana Mustadhafin yang mengajak warganet untuk membantu pekerja informal, janda/ lansia, serta anak-anak yatim dan duafa dengan mengirimkan donasi ke rekening yang telah ditentukan. Namun demikian, twit ini hanya mendapatkan 4 engagement. Twit lainnya datang dari organisasi kemahasiswaan universitas dengan nama akun @rimpala_fahutan yang mengajak warganet baik yang merupakan pengikut akun tersebut maupun warganet secara umum untuk mengirimkan donasi. Akan tetapi, twit ini tidak mendapatkan engagement.

Berdasarkan data yang diperoleh melalui data scrapping tersebut, aktor-aktor yang terlibat dalam solidaritas selama masa Pandemi COVID-19 di Twitter Indonesia tersebut dapat diklasifikasikan sebagai berikut :

Tabel 1

Klasifikasi Aktor yang Terlibat dalam Solidaritas di Twitter

\begin{tabular}{|c|c|c|c|}
\hline No & Kategori & Akun & $\begin{array}{l}\text { Jumlah } \\
\text { Pengikut }\end{array}$ \\
\hline \multirow[t]{4}{*}{1} & Individu/ & @na_dirs & 358,9 ribu \\
\hline & Personal & @najwashihab & 7,2 juta \\
\hline & & @sudjiwotedjo & 1,7 juta \\
\hline & & @ghinaghaliya & 5808 \\
\hline \multirow[t]{5}{*}{2} & Organisasi & @baznasindonesia & $14,8 \mathrm{ribu}$ \\
\hline & & @dompetdhuafaorg & $204,8 \mathrm{ribu}$ \\
\hline & & @mustadhafin & 486 \\
\hline & & @detikcom & 16,7 juta \\
\hline & & @rimpala_fahutan & 1475 \\
\hline \multirow[t]{2}{*}{3} & Komunitas & @GUSDURians & 224,3 ribu \\
\hline & & @ARMYTEAMIID & 219,8 ribu \\
\hline
\end{tabular}

Sumber: Olahan Peneliti, 2020

\section{Efektivitas Aksi Solidaritas}

Wujud gerakan solidaritas yang dilakukan oleh para aktor tercermin melalui twit yang mereka tuliskan di media sosial Twitter. Berdasarkan data yang terhimpun, terlihat bahwa masing-masing aktor mendapatkan engagement yang beragam dari para pengguna Twitter lain atas twit yang mereka tuliskan. Pada satu sisi, terdapat aktor yang mendapatkan engagement tinggi sementara di sisi yang lain terdapat pula aktor yang mendapatkan engagement rendah. Sebagai contoh, salah satu twit dari @na_dirs, yang merupakan akun personal, mendapatkan total engagement sejumlah 3.870 .

"Ada kawan2 yg sengaja order makanan lewat Ojol tapi bukan untuk dianter ke lokasi pemesan, justru untuk Ojol. Mereka juga butuh asupan agar sehat. Di saat byk yg kerja dari rumah, kita bergantung pada Ojol. Kasih mrk tips, atau belikan makanan utk mereka. Ayooo \#SalingJaga" (21 Maret 2020, @na_dirs)

Salah satu komunitas penggemar grup musik asal Korea Selatan turut pula dalam gerakan ini. Mereka mengumumkan melalui akun yakni @ ARMYTEAMIID yang pada salah satu twitnya mendapatkan engagement sejumlah 1.712 dan berhasil mengumpulkan total donasi sebesar Rp 398.764.891.

\section{"BTS ARMY INDONESIA CHARITY AGAINST} CORONA VIRUS BTS ARMY INDONESIA mengajak ARMY Se-Indonesia untuk turut berdonasi bersama untuk melawan penyebaran wabah Virus COVID-19. Adapun donasi tersebut akan secara transparan kita salurkan melalui link ini : https: $/ /$ bit.ly/2U6GsgG" (22 Maret 2020, @ ARMYTEAMIID)

Gerakan solidaritas yang terjadi tersebut juga mendapat pengaruh dari keterlibatan media massa dalam menyebarkan informasi yang dilakukan melalui Twitter. Hal tersebut dapat dilihat dari salah satu twit dari @detikcom yang memberitakan tentang penggalangan dana yang dilakukan oleh penyanyi Didi Kempot sebelum meninggal. Twit tersebut mendapatkan total engagement 7290 dan menjadi twit dengan engagement tertinggi.

"Sebelum meninggal, Didi Kempot disebut menyumbangkan $\mathrm{Rp}$ 7,6 miliar dari hasil penggalangan donasi untuk perangi pandemi COVID-19. \#DidiKempot” (5 Mei 2020, @ detikcom)

Namun demikian tidak semua aktor yang terlibat dalam gerakan solidaritas tersebut mampu mendapatkan engagement yang tinggi di media sosial Twitter. Sebagai contoh, beberapa 
akun berikut mendapatkan engagement yang sedikit meskipun jika dilihat dari narasi yang disampaikan tidak jauh berbeda dengan akun yang mendapatkan engagement tinggi. Sebuah twit dari lembaga pengelola zakat Dana Mustadhafin yang mengajak warganet untuk membantu pekerja informal, janda/ lansia, serta anak-anak yatim dan duafa dengan mengirimkan donasi ke rekening yang telah ditentukan. Namun, twit ini hanya mendapatkan 4 engagement.

"SEMBAKO PEDULI COVID Dalam rangka Program Paket Sembako Peduli Covid-19. Kembali Dana Mustadhafin mengajak kepada para Donatur utk membantu saudarasaudara kita yg terdampak Covid-19 dalam penyaluran paket sembako Tahap ke-4. Dana Mustadhafin \#pedulidanterpercaya \#pedulicovid" (2 juli 2020, @mustadhafin)

Twit yang lain datang dari individu dengan nama akun@elang_bisma yang mengajak warganet untuk mengirimkan donasi yang akan digunakan untuk membantu masyarakat Cirebon yang ekonominya terdampak COVID-19. Twit ini hanya mendapatkan 4 engagement.

"Assalamualaikum teman-teman semuanya. Disini mau ngajak kalian buat ikutan \#YukBerbagi untuk saudara kita yang berada diwilayah Cirebon dan sekitarnya yang ekonominya terdampak Covid-19. \#YukBerbagi \#PeduliCovid \#YukBersedekah \#Donasi \#Infaq \#Peduli \#Cirebon

Selain itu twit dari organisasi kemahasiswaan universitas dengan nama akun rimpala_fahutan yang mengajak warganet baik yang merupakan pengikut akun tersebut maupun warganet secara umum untuk mengirimkan donasi. Namun twit ini tidak mendapatkan engagement.

"UPDATE OPEN DONATION \#PEDULICOVID] Halo Akang Teteh Rimpala. Sebagai informasi, Alhamdulillah donasi yang telah terkumpul hingga tanggal 5 Mei 2020 sebesar: Rp. 545.,000,- Open donation dari Akang Teteh dan teman teman telah dibuka hingga tanggal 15 Mei 2020" (16 Mei 2020, @ rimpala_fahutan)

\section{Diskusi}

Twitter telah menjadi ruang untuk melakukan aksi solidaritas. Pandemi COVID-19 yang melanda dunia, termasuk Indonesia, telah menggerakkan pengguna Twitter untuk memberikan respons yang merupakan bentuk keresahan dari warganet atas situasi krisis yang sedang terjadi. Hasil penelitian menemukan dua isu utama yang menarik untuk didiskusikan lebih lanjut, yakni terkait kemunculan aksi solidaritas di Twitter dan siapa saja aktor yang berada di baliknya, serta efektivitas dari aksi solidaritas tersebut.

Analisis konten pada data buzzword atau kata yang paling sering digunakan pada setiap kata kunci dan tagar yang digunakan sebagai basis data, memberikan gambaran bahwa respons diarahkan pada isu kesehatan dan ekonomi. Berangkat dari keresahan atas situasi krisis yang terjadi, aksi solidaritas kemudian bermunculan. Data buzzword menunjukkan bahwa isi konten twit pada tiga kata kunci dan dua tagar yang dianalisis setidaknya memuat tiga unsur. Pertama, penggunaan kata persuasif yang bertujuan untuk mengajak membantu satu sama lain. Kedua, kata yang digunakan untuk menjelaskan situasi krisis kesehatan maupun ekonomi yang sedang terjadi. Dan yang terakhir, terkait dengan bentuk aksi solidaritas yang dilakukan.

Data endgraf dari tiga kata kunci dan dua tagar juga menunjukkan adanya variasi aktor. Aksi solidaritas tersebut dimunculkan oleh aktor-aktor yang dapat diklasifikasikan menjadi tiga jenis, diantaranya: individu, organisasi, dan komunitas. Aktor-aktor tersebut, walaupun sama-sama merespons situasi krisis yang terjadi dan melakukan aksi solidaritas dalam rentang waktu yang sama, mereka tidak memiliki keterkaitan atau keterhubungan satu sama lain. Aksi solidaritas dilakukan secara pribadi (personal) oleh masing-masing akun Twitter. Hal ini sejalan dengan apa yang diuraikan Bennett \& Segerberg (2012) mengenai tipologi self-organizing network. Bahwa sebuah gerakan dilakukan tanpa adanya struktur hierarki organisasi untuk mengoordinasikan aksi. Kesamaan pandangan terhadap suatu isu menjadi faktor yang menyebabkan individu melakukan aksi solidaritas.

Twit yang muncul merupakan bentuk ekspresi personal, alih-alih ekspresi dari sebuah 
Kristianto, Abdul Basith Ramadhan, Fernandito Dikky Marsetyo - Media Sosial dan Connective Action: Studi Kasus Penggunaan Twitter sebagai Ruang Solidaritas selama Pandemi COVID-19

kelompok. Konten twit juga menggambarkan kerangka tindakan pribadi yang menekankan pada inklusivitas dan berbagi opini, pengalaman, maupun keresahan pribadi. Dengan demikian, dalam konteks pandemi COVID-19, walaupun aksi solidaritas dilakukan untuk merespons isu yang sama, aksi solidaritas di Twitter, dilakukan secara personal, baik oleh individu, organisasi, maupun komunitas. Hal ini membuat bentuk aksi solidaritas di Twitter menjadi variatif (beragam).

Aksi solidaritas di Twitter selama pandemi COVID-19 juga menggambarkan apa yang disebut sebagai connective action. Seperti yang dijelaskan oleh Bennett \& Segerberg (2012) bahwa connective action lebih mengandalkan tindakan individu daripada tindakan kolektif. Walaupun sama-sama merespons isu kesehatan dan ekonomi, masing-masing akun Twitter berupaya melakukan aksi solidaritas secara personal.

Selanjutnya, isi konten twit telah memuat adanya narasi berupa kata ajakan untuk membantu satu sama lain, adanya kata yang digunakan untuk menjelaskan situasi krisis kesehatan dan ekonomi, dan bentuk aksi solidaritas yang dilakukan. Hal ini sejalan dengan pendapat Lim (2013) bahwa gerakan di media sosial dapat memobilisasi dukungan ketika berhasil mencapai tiga hal, diantaranya: adanya narasi yang disederhanakan (simplified narratives), adanya representasi simbolik (symbolic representation), dan aktivisme berisiko rendah (low-risk activism). Narasi berupa ajakan untuk membantu sesama dibingkai sedemikian rupa untuk mendapat perhatian warganet. Sebagai contoh, penggunaan kata "ayo" dan "bantu" merepresentasikan bahwa narasi ajakan (yang bersifat persuasif) untuk saling membantu satu sama lain. Berangkat dari narasi tersebut, muncul adanya representasi simbolik. Sebagai contoh, hal ini dapat dilihat melalui kata "masker" dan "sembako" yang menunjukkan bahwa para pengguna Twitter mengarahkan respons mereka pada dua sektor utama, yakni kesehatan dan ekonomi. Kedua contoh kata tersebut merupakan representasi simbolik dari aksi solidaritas yang dilakukan. Berbagai aksi solidaritas menggambarkan aktivisme yang berisiko rendah (low-risk activism), di mana seluruh aksi solidaritas mengarah pada respons atas situasi krisis.

Namun demikian, tidak semua aksi solidaritas mendapatkan impresi atau engagement yang tinggi dari warganet. Seperti yang dijelaskan sebelumnya, twit berupa aksi solidaritas tidak muncul dengan sendirinya (Jungherr, 2015), melainkan terdapat aktor yang berada di baliknya (Park, 2013; Zhang et al., 2016).

Sebagai contoh, twit yang mendapatkan impresi tinggi didapatkan oleh akun@ NajwaShihab, @na_dirs, @detiknewsdan @ ARMYTEAMIID yang memiliki pengikut secara berurutan sejumlah 7,2 juta, 358,9 ribu, 16,7 juta

\section{Gambar 6 \\ Grafik Perbandingan Pengikut dan Impresi Aktor}

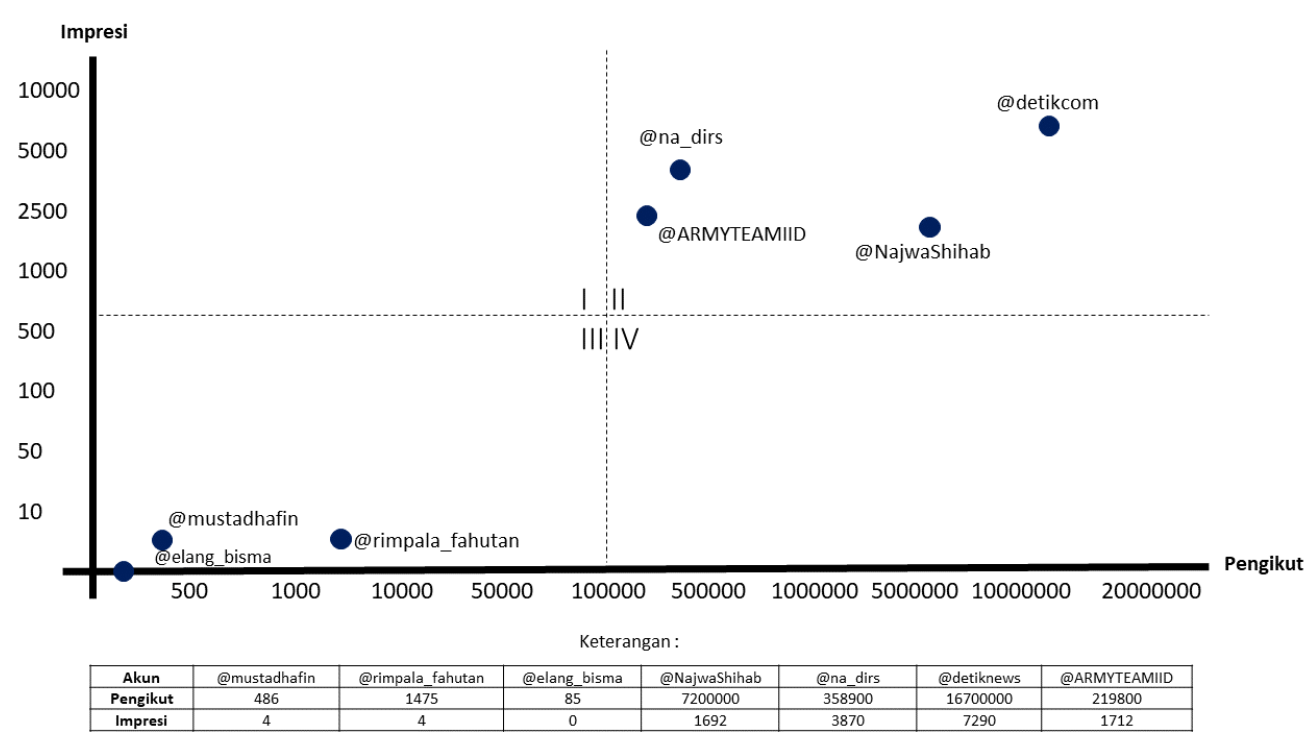

Sumber : Olahan Peneliti, 2020 
dan 219,8 ribu. Kepemilikan jumlah pengikut sejumlah itu berkorelasi dengan impresi tinggi yang mereka dapatkan, yakni sejumlah 1.692 (@NajwaShihab), 3.870 (@na_dirs), 7.290 (@detikcom),dan 1.712 (@ARMYTEAMIID). Sementara itu, akun dengan jumlah pengikut yang rendah, cenderung mendapatkan impresi yang lebih rendah. Sebagai contoh akun@ mustadhafin, @rimpala_fahutan, dan @elang_ bisma. Akun-akun tersebut memiliki pengikut sejumlah 486, 1475, dan 85 yang secara berurutan mendapatkan impresi sejumlah 4 , 4, dan 0.

Gambaran tersebut sejalan dengan pendapat Jungherr (2015), Park (2013), Zhang et al. (2016), dan Xu et al. (2014), bahwa aktor-aktor yang mendapatkan impresi tinggi disebut sebagai opinion leader yang mana memiliki efektivitas yang tinggi dalam merespons situasi krisis yang terjadi. Efektivitas tersebut dilihat dari pengaruh yang besar dalam penyebaran informasi di media sosial yang diukur melalui tiga hal, diantaranya: indegree (jumlah pengikut suatu akun di Twitter), retweet (jumlah twit yang dibuat pengguna yang telah di-retweet oleh akun lainnya), dan mention (berapa kali suatu akun disebutkan ditwit pengguna lain). Ketiga ukuran tersebut kemudian disebut sebagai impresi/engagement. Penelitian ini menemukan bahwa aktor yang memiliki pengikut dalam jumlah besar memiliki kecenderungan untuk mendapatkan impresi yang tinggi dan berada pada kuadran II. Begitu pula sebaliknya, aktor yang memiliki pengikut dalam jumlah sedikit memiliki kecenderungan mendapatkan impresi yang rendah dan berada pada kuadran III (lihat Gambar 8.). Dengan demikian dapat dikatakan bahwa dalam merespons situasi krisis pandemi COVID-19 di Indonesia melalui Twitter, aktor yang menjadi opinion leader memiliki pengaruh yang lebih besar dalam melakukan aksi solidaritas.

\section{Kesimpulan}

Tulisan ini berusaha menjelaskan bagaimana aksi solidaritas muncul di Twitter sebagai respons atas kondisi pandemi COVID-19 yang berdampak pada dua sektor utama, yaitu sektor kesehatan dan ekonomi. Tulisan ini juga menganalisis bagaimana pola gerakan yang dilakukan oleh berbagai aktor di Twitter selama pandemi COVID-19 muncul dalam rentang waktu 14 Maret 2020 sampai dengan
31 Juli 2020. Selain itu, tulisan ini juga mencoba melihat sejauh efektivitas gerakan solidaritas yang dilakukan oleh beragam aktor tersebut. Terdapat tiga inti sari utama dari penelitian ini.

Pertama, aksi solidaritas ini memiliki beragam variasi aktor yang diklasifikasikan dalam tiga jenis, yaitu individu, organisasi, dan komunitas. Meskipun aktor-aktor tersebut melakukan solidaritas dalam waktu yang bersamaan, namun mereka tidak memiliki keterhubungan satu dengan lainnya. Aksi solidaritas berangkat dari keresahan pribadi, alih-alih ekspresi dari sebuah kelompok. Adanya kesamaan pandangan atau keresahan yang sama atas isu pandemi, mendorong mereka melakukan aksi solidaritas. Para aktor menggunakan cara yang beragam dalam menggambarkan keresahan pribadi untuk berbagi (sharing) opini atau pengalaman mereka di Twitter. Hal tersebut menyebabkan adanya variasi gerakan dalam melakukan aksi solidaritas, namun memiliki tujuan yang sama yaitu ajakan untuk saling membantu satu sama lain.

Kedua, terdapat tiga unsur dalam twit aksi solidaritas yang dilakukan oleh para aktor. Pertama, adanya narasi persuasif sederhana yang terbentuk dan dapat memikat perhatian pengguna lain. Kedua, narasi persuasif tersebut diikuti dengan kata kunci yang menjadi simbol dari objek aksi solidaritas. Ketiga, aksi solidaritas yang terjadi menggambarkan aktivisme yang berisiko rendah (low-risk activism), di mana seluruh aksi solidaritas mengarah pada respons atas situasi krisis.

Akhirnya, meskipun para aktor menggunakan narasi yang sama, namun terdapat perbedaan impresi/engagement di antara aktor tersebut. Hal ini tidak dapat dilepaskan dari akun yang menjadi opinion leader yang dilihat dari jumlah pengikut, jumlah retweet, dan jumlah mention suatu akun. Dengan demikian, dalam merespons situasi krisis pandemi COVID-19 di Indonesia melalui Twitter, aktor yang menjadi opinion leader memiliki pengaruh yang lebih besar dalam melakukan aksi solidaritas.

\section{Referensi}

Ahyar, M., \& Alfitri, A. (2019). Aksi Bela Islam: islamic clicktivism and the new authority of religious propaganda in the millennial age in Indonesia. Indonesian Journal of Islam and Muslim Societies, 9(1), pp. 1-29 https://doi.org/10.18326/ijims.v9i1. 
Kristianto, Abdul Basith Ramadhan, Fernandito Dikky Marsetyo - Media Sosial dan Connective Action: Studi Kasus Penggunaan Twitter sebagai Ruang Solidaritas selama Pandemi COVID-19

Anggraeni, L. (2020). Ini Inisiatif yang Muncul di Twitter Selama Pandemik Covid-19. Medcom.Id.https://www.medcom.id/tek nologi/news-teknologi/nbwjXejN-ini-i nisiatif-yang-muncul-di-twitter-selama-pa ndemik- covid-19

Ausserhofer, J., Mairader, A. (2013). National Politics on Twitter Structures and Topics of a Networked Public Sphere. Information, Communication \& Society, 16(3), pp. 291-314.

Basri, M. C. (2020). Ekonomi dalam Normal Baru. Kompas.

Bennett, W. L., \& Segerberg, A. (2012). THE LOGIC OF CONNECTIVE ACTION. Information, Communication \& Society, 15(5), pp. 739-768. doi: doi.org/10.1080/136911 8X.2012.670661

Bennett, W. L., \& Segerberg, A. (2013). The Logic of Connective Action (Pertama). Cambridge University Press. doi: doi.org/10.1017/ CB09781139198752

Bimber, B. (2017). Three Prompts for Collective Action in the Context of Digital Media. Political Communication, 34(1), pp. 6-20.doi: doi.org/10.1080/10584609. 2016.1223772

CNBC Indonesia. (2020). WHO: Corona Bongkar Betapa Buruknya Sistem Kesehatan Dunia.https://www.cnbcin donesia.com/lifestyle/202003311335 59-33-148750/who-corona-bongkarbetapa-buruknya sistem-kesehatan-dunia

Fammy, N. S., Bambang, A., \& Hapsari, D. T. (2020). Fenomena Caption "Twitter, Please Do Your Magic!" Membangkitkan Netizen untuk Menolong. Journal of Digital Education, Communication, and Arts, 3(1), pp. 30-39.

Fisse, T., \& Hass, C. (2020). Covid-19 and True Solidarity on the Internet.

Google. (2020). COVID-19 Community Mobility Report.

Herman, \& Mononimbar, D. A. (2017). Indonesia Fifth Largest Country in Terms of Twitter Users. https://jakartaglobe.id/news/ indonesia-fifth-largest-country-in-termsof-twitter-users/

Iosifidis, P., \& Wheeler, M. (2016). Social Media, Public Sphere and Democracy. In Public Spheres and Mediated Social Networks in the Western Context and Beyond ( pp. 13-37). Palgrave Macmillan UK. https://doi.org/10.1057/978-1-137-41030 $-6 \_2$
Jungherr, A. (2015). Twitter as Political Communication Space: Publics, Prominent Users, and Politicians. In Analyzing Political Communication with Digital Trace Data (pp. 69-106). Springer International Publishing. doi: doi. org/10.1007/978-3-319-20319-5_4

Kemenko PMK. (2020). Pembatasan Sosial Berskala Besar. https://www.kemenkopmk. go.id/pembatasan-sosial-berskala-besar

Kompas. (2020a). Fakta Lengkap Kasus Pertama Virus Corona di Indonesia. https:// nasional.kom pas.com/read/2020/03/03/06314 981/fakta-lengkap-kasus-pertama-viru $\mathrm{s}$-corona-di-indonesia?page $=$ all

Kompas. (2020b). Presiden Jokowi: Stok Semakin Terbatas, RI Butuh 3 Juta APD. https://nasional.kompas.com $/ \mathrm{read} / 2020 / 03 / 30 / 14485691 /$ presiden-j okowi-stok-semakin-terbatas-ri-butuh-3juta-apd

Kontan. (2020). Bisnis UMKM olahan makanan paling terdampak corona. https://nasional. kontan.co.id/news/bisnis-umkm-olahanmakanan-paling-terdampak-corona

Kumparan. (2020). Kumpulkan Donasi Rp 1,5 Miliar, Ashanty Salurkan APD untuk 300 Rumah Sakit. Kumparan.com. https:// kumparan.com/kumparanhits/kumpulkandonasi-rp-1-5-miliar-ashanty-salurkan-apduntuk-300-rumah-sakit-1tG8Ms5jhUZ

Lim, M. (2013). Many Clicks but Little Sticks: Social Media Activism in Indonesia. Journal of Contemporary Asia, 43(4), pp. 636-657. doi.org/ 10.1080/ 00472336.201 3.769386

Luarn, P., Yang, J.C., \& Chiu, Y.-P. (2014). The network effect on information dissemination on social network sites. Computers in Human Behavior, 37, pp. 1-8. doi: doi.org/ 10.1016/j. chb.2014.04.019

Mia C. D. (2020). 4 Inisiatif Galang Donasi Virus Corona di Twitter. Bisnis.Com.https://lifestyle.bisnis.com/ $\mathrm{read} / 20200428 / 219 / 1233589 / 4$-inisiatifgalang-donasi-virus-corona-di-twitter

Park, C. S. (2013). Does Twitter motivate involvement in politics? Twiting, opinion leadership, and political engagement. Computers in Human Behavior, 29(4),pp. 1641-1648. doi: doi.org/ 10.1016/j. chb.2013.01.044 
Raditya, D. (2020). Gotong Royong Hadapi Pandemi: Karena Hidup Bukan Hanya Soal Diri Sendiri. Chub Fisipol UGM. https:// chub.fisipol.ugmacid/2020/06/09/ gotong-royong-hadapi-pandemi/

Satuan Tugas Penanganan COVID-19 Indonesia. (2020). Peta Sebaran. https://covid19.go.id/ peta-sebaran

Stieglitz, S., \& Dang-Xuan, L. (2013). Social media and political communication: a social media analytics framework. Social Network Analysis and Mining, 3(4), pp.1277-1291. doi: doi. org/ 10.1007/ s13278-012-0079-3

Suwana, F. (2020). What motivates digital activism? The case of the Save KPK movement in Indonesia. Information, Communication \& Society, 23(9), pp. 1295-1310. doi: doi.org/ 10.1080/ 1369118X.2018.1563205

Syambudi, I. (2020). Aksi Solidaritas Pandemi Corona: Dapur Umum Hingga Donasi Rp50 Juta. Tirto.Id. https://tirto.id/aksisolidaritas-pandemi-corona-dapur-umumhingga-donasi-rp50-juta-eJVL

Tirto. (2020). COVID-19 RI: Di Antara Ilusi Rasa Aman \& Potensi Kolaps Layanan RS? https:// tirto.id/covid-19-ri-di-antara-ilusi-rasaaman-potensi-kolaps-layanan-rs-fYLi

Viva. (2020). IDI Akui Dokter Kekurangan APD untuk Tangani Pasien Corona. https:// www.viva.co.id/berita/nasional/1268587idi-akui-dokter-kekurangan-apd-untuktangani-pasien-corona?medium=autonext

Wiharso, A. (2020). Agar UMKM Tak Mati Karena Pandemi. Detik.com. https://news.detik. com/kolom/d-5060170/agar-umkm-takmati-karena-pandemi
World Health Organization. (2020a). COVID-19: Physical Distancing. https://www.who.int/ west ernpacific/emer gencies/co vid-19/ information/physical-distancing

World Health Organization. (2020b). Penggunaan rasional alat perlindungan diri untuk penyakit coronavirus (COVID-19) dan pertimbangan jika ketersediaan sangat terbatas. https://www.who.int/docs/ default-source/searo/indonesia/covid19/ who-2019-penggunaan-rasional-alatperlindungan-diri-untuk-covid-19-danpertimbangan.pdf?sfvrsn=7eb7ebc7_2

World Health Organization. (2020c). Rolling update on coronavirus disease (COVID-19). https://www.who.int/emergencies/ diseases/novel-coronavirus-2019/eventsas-they-happen

World Health Organization. (2020d). WHO Coronavirus Disease (COVID-19) Dashboard. https://covid19.who.int/

Xu, W. W., Sang, Y., Blasiola, S., \& Park, H. W. (2014). Predicting Opinion Leaders in Twitter Activism Networks. American Behavioral Scientist, 58(10), pp.1278-1293. doi: doi. org/ 10.1177/ 0002764214527091

Zeng, D., Chen, H., Lusch, R., \& Li, S.-H. (2010). Social Media Analytics and Intelligence. IEEE Intelligent Systems, 25(6), pp. 13-16. doi: https:// doi.org/10.1109/MIS.2010.151

Zhang, L., Zhao, J., \& Xu, K. (2016). Who creates Trends in Online Social Media: The Crowd or Opinion Leaders? Journal of ComputerMediated Communication, 21(1), pp. 1-16. https://doi.org/10.1111/jcc4.12145 